\title{
Association between perceived social support and better cognitive performance among caregivers and non-caregivers
}

\author{
Associação entre suporte social percebido e melhor desempenho cognitivo entre cuidadores e não cuidadores \\ Asociación entre apoyo social percibido y mejor desempeño cognitivo entre cuidadores y no cuidadores
}

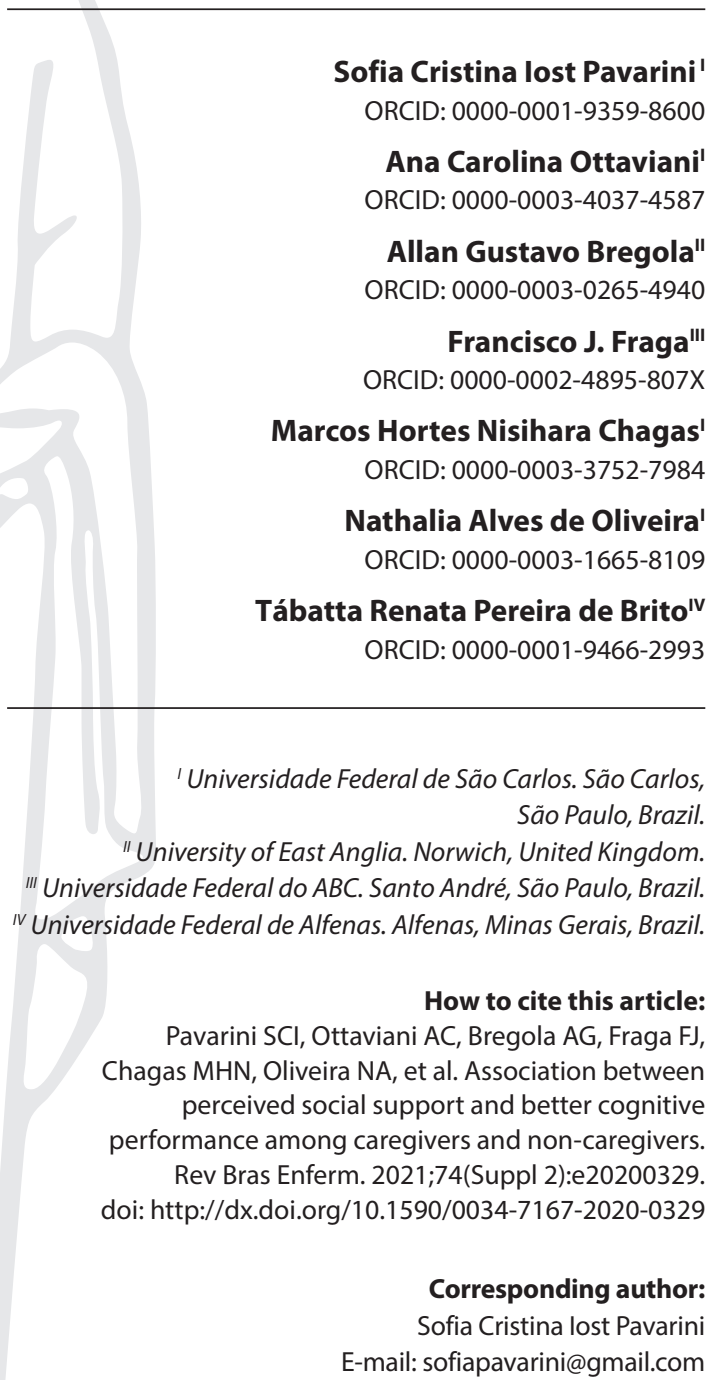

EDITOR CHEFE: Antonio José de Almeida Filho EDITOR ASSOCIADO: Andrea Bernardes

Submission: $22-04-2020$

Approval: 06-10-2020

\section{ABSTRACT}

Objective: to identify the association between the characteristics of the support network and cognitive performance of older caregivers and compare characteristics between caregivers and non-caregivers. Methods: we evaluated 85 older caregivers and 84 older non-caregivers registered with primary care units regarding sociodemographic characteristics, cognition, and social support. Multiple linear regression analysis was performed. Results: among noncaregivers, significant associations were found between a better cognitive performance and receiving emotional/affectionate support; each one-point increase in the emotional support score and affectionate support score was related to a 0.43-point and 0.39-point increase in cognitive assessment, respectively. Among older caregivers, each one-point increase in the emotional support score was related to a 0.55 -point increase in cognitive assessment. Conclusion: strengthening the support networks of older caregivers and encouraging satisfactory exchanges of social support can assist in improving cognitive performance, which can have a positive impact on caregivers' health.

Descriptors: Aged; Caregivers; Cognition; Social Support; Geriatric Nursing.

\section{RESUMO}

Objetivo: identificar a associação entre as características da rede de apoio e o desempenho cognitivo de cuidadores idosos e comparar características entre cuidadores e não cuidadores. Método: foram avaliados 85 idosos cuidadores e 84 idosos não cuidadores cadastrados em unidades da atenção primária de saúde quanto às características sociodemográficas, cognitivas e suporte social. Foi realizada análise de regressão linear múltipla. Resultados: entre os não cuidadores, foram encontradas associações significativas entre melhor desempenho cognitivo e receber apoio emocional/afetivo; cada aumento de um ponto no escore de apoio emocional e escore de suporte afetivo foi relacionado a um aumento de 0,43 pontos e 0,39 pontos na avaliação cognitiva, respectivamente. Entre os cuidadores mais velhos, cada aumento de um ponto na pontuação do apoio emocional teve relação com um aumento de 0,55 ponto na avaliação cognitiva. Conclusão: o fortalecimento das redes de apoio de cuidadores mais velhos e o incentivo a trocas satisfatórias de apoio social podem auxiliar na melhoria do desempenho cognitivo, o que pode impactar positivamente na saúde dos cuidadores. Descritores: Idoso; Cuidadores; Apoio Social; Enfermagem Geriátrica.

\section{RESUMEN}

Objetivo: identificar la asociación entre las características de la red de apoyo y el desempeño cognitivo de los cuidadores mayores y comparar características entre cuidadores y no cuidadores. Métodos: se evaluaron 85 cuidadores mayores y 84 no cuidadores mayores registrados en unidades de atención primaria en cuanto a características sociodemográficas, cognitivas y de apoyo social. Se realizó un análisis de regresión lineal múltiple. Resultados: entre los no cuidadores, se encontraron asociaciones significativas entre un mejor desempeño cognitivo y recibir apoyo emocional/afectivo; cada aumento de un punto en la puntuación de apoyo emocional y la puntuación de apoyo afectivo se relacionó con un aumento de 0,43 puntos y 0,39 puntos en la evaluación cognitiva, respectivamente. Entre los cuidadores mayores, cada aumento de un punto en la puntuación de apoyo emocional se relacionó con un aumento de 0,55 puntos en la evaluación cognitiva. Conclusión: el fortalecimiento de las redes de apoyo para los cuidadores mayores y el fomento de intercambios satisfactorios de apoyo social puede ayudar a mejorar el rendimiento cognitivo, lo que puede tener un impacto positivo en la salud de los cuidadores.

Descriptores: Anciano; Cuidadores; Apoyo Social; Enfermería Geriátrica 


\section{INTRODUCTION}

Providing care for older persons is one of the most pressing issues on research agendas throughout the world. The increase in life expectancy has led to sociocultural, epidemiological, and economic changes with new demands related to the care of older adults. Such changes include the growing need for longterm care and the higher number of older family members who provide care for dependent older adults ${ }^{(1)}$.

The activity of care provision requires adequate cognitive processing and a strong performance regarding cognitive skills, such as attention, memory, planning, and logical reasoning ${ }^{(2)}$. The literature reports that the burden generated by an excess of care activities can exert negative impacts on one's physical, cognitive, and psychological health with the prevalence of emotional stress, depressive symptoms, anxiety, physical exhaustion and difficulty sleeping as well as limitations of work, social and leisure activities, thereby contributing to the reduction of wellbeing and quality of life ${ }^{(3-6)}$.

Studies have shown the importance of a social support network to the health of caregivers ${ }^{(3,7-8)}$. Researchers have evaluated such networks as one of the main modifiable tools for interventions aimed at improvements in quality of life and overall health. Social support networks are defined as a set of social relations maintained by individuals that enable the exchange of different types of support (financial, emotional, and tangible) and constitute an integral part of senior health ${ }^{(9-10)}$.

A literature review reported that social support is a determinant of healthy ageing and should be stimulated in general society by professionals in different fields ${ }^{(10)}$. According to researchers, the importance of social support increases in old age ${ }^{(10-12)}$ and is a predictor of better levels of mental health ${ }^{(13)}$, absence of depression $^{(14-15)}$, absence of physical disability ${ }^{(16)}$, and of improvements in wellbeing and quality of life $\mathrm{e}^{(17-18)}$.

Concerning the relation between cognition and social support, researchers in the United States evaluated a sample of 3310 older adults to determine if the early stages of cognitive impairment are related to any of the multiple characteristics of social support, and found that those at risk of mild cognitive impairment and premature dementia had diminished social support resources ${ }^{(19)}$. In a systematic review of the literature, 19 longitudinal articles were analyzed to investigate the association between social support and dementia, and it was found that little participation in social activities, little social contact, and feelings of loneliness were significantly associated with the risk of incident dementia ${ }^{(20)}$.

Low-, and middle-income countries need fast, effective strategies. The accelerated ageing of the population and insufficiency of services to meet the demands of such a population make care for older adults a public health problem and produces an increasing number of older caregivers who provide care for dependent family members. Cross-sectional studies are needed to evaluate the influential role of social support on the cognitive health of caregivers and the quality of the care offered. Such investigations can pave the way for longitudinal and interventional studies and policies directed at care management.

Considering the importance of the issues of care, cognition, and social support and the insufficiency of studies addressing these variables in the population of older caregivers, we test the hypothesis of an association between perceived social support and a better cognitive performance in older caregivers.

\section{OBJECTIVE}

Identify the association between social network characteristics and cognitive performance among older caregivers and compare the results to those found for older non-caregivers.

\section{METHODS}

\section{Ethical aspects}

This study was authorized by the Municipal Health Secretariat of the municipality and approved by the Research Ethics Committee of the Federal University of São Carlos. Participation was voluntary and all participants signed an informed consent form.

\section{Design, study place and period}

This is an observational, cross-sectional, quantitative study, in which the STROBE guidelines were followed. The study was conducted in 15 Family Health Units in a city in the countryside of the state of São Paulo. Data collection was performed between June 2016 and July 2017 in two steps, through individual interviews conducted by previously trained undergraduate students.

\section{Population and sample: inclusion and exclusion criteria}

The sample size was calculated using the method for comparing means between two groups, considering a 5\% significance level (type I error) and $80 \%$ sample power (20\% beta or type II error) ${ }^{(21)}$. Mean and standard deviation values were estimated from a pilot study conducted with older caregivers and non-caregivers registered at heath units. A minimum of 41 participants per group was estimated. Considering a possible sample loss, we selected an initial convenience sample of $n=233$ older persons, of which 11 had died, 46 refused to participate and seven did not complete all instruments. The final sample comprised 85 older caregivers and 84 older non-caregivers.

The following criteria were used for the inclusion of individuals in the respective groups: older caregivers - age 60 years or older registered at one of the primary care units in the city and being the primary caregiver of a dependent older adult residing in the same home. A dependent older adult was considered anyone who reported dependence on at least one basic activity of daily living (BADL) or instrumental activity of daily living (IADL). The BADL was based on the Katz Index validated for the Brazilian context. The total scale score is calculated as the sum of items and may range from 0 points (dependent for all functions) to 6 points (independent for all functions) ${ }^{(22)}$. The IADL was evaluated by the Brazilian version of the Lawton and Brody Scale, the total score ranges from 7 to 21 points; scores of 7 indicate total dependence, 8-20 points partial dependence, and 21 points independence ${ }^{(23)}$. These instruments were also administered to the older caregiver, who needed to be more independent than the older adult receiving care.

Older non-caregivers were those aged 60 years or older, registered at one of the primary care units in the city, not offering 
primary care to an older adult, and residing alone or with another family member who is not an older person. The exclusion criteria were all older adults in the residence classified as independent for BADLs and IADLs in the group of older caregivers, self-reported neurological disorder, alcoholism, or the use of psychoactive drugs.

\section{Study protocol}

In the first step, the interviewers visited the homes of older adults obtained from lists provided by primary care services for the assessment of eligibility criteria. When these criteria were met, interviewers collected data on sociodemographic, healthrelated, care-related, and social support characteristics from all older caregivers who agreed to participate in the study. A second interview was scheduled within a maximum of one week. In the second step, interviewers collected data on cognitive performance and depressive symptoms. This step was performed at a previously defined location of easy access in the neighborhood in order to ensure a quiet, well-lit environment for participants.

For the sociodemographic and health-related characterization, a structured script was used, including information on sex (female or male), age (in years), schooling (in years), marital status (with or without a partner), monthly family income (in Brazilian currency $[R \$])$, number of residents in the home, and number of diseases.

The Brazilian version of the Medical Outcomes Study (MOS) was used for the assessment of social support. It has 19 items addressing five domains of social support: tangible, affectionate, emotional, positive social interaction, and informational. For all questions, five answer options were presented ranging from 1 to 5 , with 1 being never and 5 always. The score of each domain ranges from 20 to 100 points, and higher points indicate a greater level of social support ${ }^{(24)}$.

The assessment of cognitive performance was based on the Addenbrooke's Cognitive Examination - Revised (ACE-R) validated for the Brazilian context. The ACE-R is composed of five domains: orientation/attention (18 points), memory (26 points), verbal fluency (14 points), language ( 26 points) and visuospatial abilities ( 16 points). The overall score ranges from 0 to 100 points, where the higher the score, the better the cognitive performance ${ }^{(25)}$. For the analyzes of the present study, the scores were used in a continuous manner.

The Brazilian version of the Geriatric Depression Scale (15-item version) was used in depressive symptoms assessment. The questions are in "yes" (1 point) or "no" (zero) format. The final score is determined by summing the item scores, which range from 0 to 15 points, with a cutoff of 5/6 points (non-case/case) indicating depressive symptoms. A score higher than 10 points is considered indicative of a greater severity of depressive symptoms ${ }^{(26)}$. In the present study, the number of self-reported symptoms was counted.

\section{Analysis of results}

Data were coded, entered onto an electronic spreadsheet, and analyzed with the aid of the Stata statistical package, version 13. Descriptive statistics were performed for the estimates of frequency distribution as well as mean and standard deviation values for the continuous variables. Proportions were estimated for the categorical variables. The Kolmogorov-Smirnov was used to test the normality of data. Means were compared using the t-test and Mann-Whitney test. Differences between groups were estimated using the Pearson's chi-square test. Pearson's correlation coefficients were calculated for the determination of the strength of correlations between variables. The association analysis was performed using multiple linear regression analysis stratified by group (caregivers/non-caregivers). The models including the support domains (tangible, affectionate, emotional, positive social interaction, and informational) and number of members in the network were adjusted for sex, age, schooling, number of diseases, and number of depressive symptoms. Data were normally distributed in the analysis of residuals of the models. The level of significance was set at $5 \%$.

\section{RESULTS}

Among the overall sample, $50.3 \%(n=85)$ were caregivers of other older adults. Table 1 displays the socioeconomic, healthrelated, and social support characteristics of older caregivers and non-caregivers. Statistically significant differences were found for marital status, number of residents in the home, and monthly family income. The proportion of older adults who lived with a partner was higher among caregivers (83.3\%) than non-caregivers (16.7\%) $(p=0.001)$. The mean number of residents in the home was 2.1 among caregivers and 2.4 among non-caregivers $(p=0.001)$. Mean monthly family income was higher among caregivers ( $R \$ 2,259.80$ vs. $R \$$ $1,674.90)(p=0.001)$. No significant differences between groups were found for the number of diseases or depressive symptoms.

Table 1 - Distribution of sociodemographic, health-related, and social support characteristics among older caregivers and non-caregivers $(\mathrm{N}=169)$, São Carlos, São Paulo, Brazil, 2017

\begin{tabular}{lccc}
\hline \multicolumn{2}{c}{ Caregiver } & \\
& $\begin{array}{c}\text { Yes } \\
\text { Mean (SD) }\end{array}$ & Mean (SD) & \\
\hline Sex & & & \\
$\quad$ Male & $37.8 \%$ & $62.2 \%$ & $0.086^{3}$ \\
$\quad$ Female & $53.8 \%$ & $46.2 \%$ & \\
Age (years) & $69.6(5.9)$ & $70.8(7.5)$ & $0.476^{4}$ \\
Marital status & & & \\
$\quad$ With partner & $83.3 \%$ & $16.7 \%$ & $0.001^{3 *}$ \\
$\quad$ Without partner & $12.8 \%$ & $87.2 \%$ & \\
Schooling (years) & $3.9(3.5)$ & $3.5(2.9)$ & $0.782^{4}$ \\
Monthly family income (R\$) & $2259.8(1299.4)$ & $1674.9(858.8)$ & $0.001^{4 *}$ \\
No of residents in home & $3.1(1.6)$ & $2.4(1.5)$ & $0.000^{4 *}$ \\
No of diseases & $4.5(2.6)$ & $4.5(2.5)$ & $0.879^{4}$ \\
No of depressive symptoms $^{1}$ & $3.7(2.7)$ & $3.6(2.7)$ & $0.646^{4}$ \\
Tangible support $^{2}$ & $87.4(18.7)$ & $87.9(25.0)$ & $0.124^{4}$ \\
Affectionate support $^{2}$ & $89.5(19.5)$ & $88.4(25.6)$ & $0.547^{4}$ \\
Emotional support $^{2}$ & $86.4(21.5)$ & $86.7(24.9)$ & $0.514^{4}$ \\
Positive social interaction $^{2}$ & $84.5(23.4)$ & $86.1(25.8)$ & $0.373^{4}$ \\
Informational support $^{2}$ & $85.4(20.8)$ & $87.4(24.5)$ & $0.076^{4}$ \\
No of members in network $^{\circ}$ & $4.9(3.4)$ & $5.0(3.4)$ & $0.944^{4}$ \\
\hline
\end{tabular}

Note: ${ }^{1}$ Number of self-reported symptoms using Geriatric Depression Scale; ${ }^{2}$ Score obtained using Social Support Scale of Medical Outcomes Study; ${ }^{3}$ Pearson's chi-squared test; ${ }^{4}$ Mann-Whitney test; ${ }^{*}$ statistically significant difference.

Regarding the characteristics of the support network, the mean perceived social support scores were higher among non-caregivers compared to caregivers for all domains, except for affectionate support. The mean number of members in the social network was also higher among non-caregivers. However, these differences did not achieve statistical significance (Table 1). 


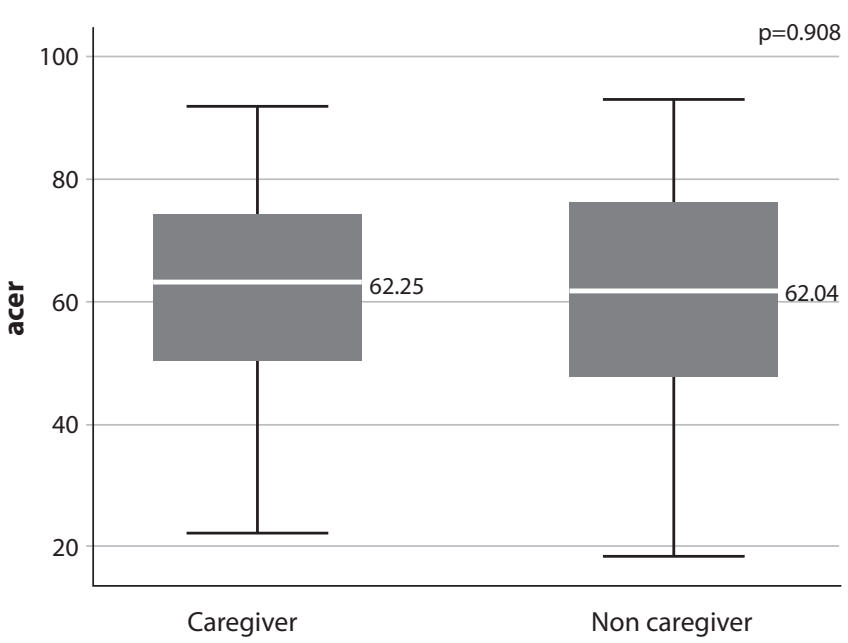

Figure 1 - Boxplot of ACE-R scores among caregivers and non-caregivers, São Carlos, São Paulo, Brazil, 2017

The mean score on the ACE-R was 62.1 points (SD: 1.32). The mean score of caregivers (62.3 points; SD: 1.8) did not differ significantly from the mean score of non-caregivers (62.0 points; SD: 1.9) (Figure 1).

Among caregivers, positive correlations were found between the ACE-R score and both family income and schooling. Among non-caregivers, positive correlations were found between the ACE-R score and family income, schooling, and the emotional support score. Among non-caregivers, the mean ACE-R score was higher among those who lived with a partner and negative correlations were found between the ACE-R and age, tangible support, informational support, positive social interaction, and number of members in the network (Table 2).

Table 2 - Correlation between mean ACE-R score and sociodemographic, health-related, and social support characteristics among caregivers and non-caregivers ( $N=169$ ), São Carlos, São Paulo, Brazil, 2017

\begin{tabular}{|c|c|c|c|c|}
\hline & \multicolumn{4}{|c|}{ Caregiver } \\
\hline & $\begin{array}{c}\text { Yes } \\
\text { Mean (SD) } \\
\text { or r } \\
\end{array}$ & $p$ & $\begin{array}{c}\text { No } \\
\text { Mean (SD) } \\
\text { or } r \\
\end{array}$ & $\boldsymbol{p}$ \\
\hline Sex & & & & \\
\hline $\begin{array}{l}\text { Male - Mean (SD) } \\
\text { Female - Mean (SD) }\end{array}$ & $\begin{array}{l}64.6(4.8) \\
61.8(1.9)\end{array}$ & $0.558^{3}$ & $\begin{array}{l}65.9(3.1) \\
60.6(2.4)\end{array}$ & $0.227^{3}$ \\
\hline Age (years) & $-0.117^{4}$ & 0.283 & $-0.377^{4}$ & $0.001^{*}$ \\
\hline $\begin{array}{l}\text { Marital status } \\
\quad \text { With partner - Mean (SD) } \\
\text { Without partner - Mean (SD) }\end{array}$ & $\begin{array}{l}61.5(1.9) \\
67.7(4.0)\end{array}$ & $0.270^{3}$ & $\begin{array}{l}70.4(4.9) \\
60.0(2.1)\end{array}$ & $0.041^{3 *}$ \\
\hline Schooling (years) & $0.493^{4}$ & $0.001^{*}$ & $0.669^{4}$ & $0.001^{*}$ \\
\hline Monthly family income (R\$) & $0.401^{4}$ & $0.001^{*}$ & $0.293^{4}$ & $0.017^{*}$ \\
\hline No of residents in home & $-0.191^{4}$ & 0.078 & $-0.046^{4}$ & 0.675 \\
\hline No of diseases & $0.001^{4}$ & 0.989 & $-0.146^{4}$ & 0.186 \\
\hline $\mathrm{N}^{\circ}$ of depressive symptoms ${ }^{1}$ & $-0.130^{4}$ & 0.861 & $-0.030^{4}$ & 0.781 \\
\hline Tangible support ${ }^{2}$ & $-0.032^{4}$ & 0.766 & $-0.305^{4}$ & $0.004^{*}$ \\
\hline Affectionate support ${ }^{2}$ & $-0.019^{4}$ & 0.861 & $-0.202^{4}$ & 0.064 \\
\hline Emotional support ${ }^{2}$ & $0.012^{4}$ & 0.910 & $0.291^{4}$ & $0.007^{*}$ \\
\hline Positive social interaction ${ }^{2}$ & $-0.050^{4}$ & 0.646 & $-0.224^{4}$ & $0.040^{*}$ \\
\hline Informational support $^{2}$ & $-0.043^{4}$ & 0.695 & $-0.316^{4}$ & $0.003^{*}$ \\
\hline$N^{\circ}$ of members in network & $-0.009^{4}$ & 0.928 & $-0.249^{4}$ & $0.025^{*}$ \\
\hline
\end{tabular}

In the analysis of the association between the characteristics of the support network and performance on the ACE-R in the group of non-caregivers, each one-point increase in the emotional support score and affectionate support score was related to a 0.43-point $(p=0.033)$ and 0.39 -point $(p=0.011)$ increase in the ACE-R score, respectively. In the group of caregivers, an association was found only between cognitive performance and emotional support, with each one-point increase in the emotional support score related to a 0.55 -point increase in the ACE-R score. In both the caregiver and non-caregiver models, the associations were independent of scores on the other social support domains; sex, age, number of diseases, and self-reported depressive symptoms. However, the associations were not independent of schooling (Table 3).

Table 3 - Multiple linear regression analysis for identification of associations between characteristics of social support network and performance on ACE-R (N = 169), São Carlos, São Paulo, Brazil, 2017

\begin{tabular}{|c|c|c|c|c|c|c|c|c|}
\hline & \multicolumn{8}{|c|}{ Carer } \\
\hline & \multicolumn{4}{|c|}{ Yes } & \multicolumn{4}{|c|}{ No } \\
\hline & $\beta$ & $p$ & $\begin{array}{c}p \\
\text { (model) }\end{array}$ & $r^{2} a$ & $\beta$ & $p$ & $\underset{\text { (model) }}{p}$ & $r^{2} a$ \\
\hline Tangible support & -0.34 & 0.094 & 0.001 & 0.32 & 0.11 & 0.416 & 0.000 & 0.59 \\
\hline Affectionate support & -0.05 & 0.762 & & & 0.39 & 0.011 & & \\
\hline Emotional support & 0.55 & 0.044 & & & 0.43 & 0.033 & & \\
\hline $\begin{array}{l}\text { Positive social } \\
\text { interaction }\end{array}$ & -0.09 & 0.459 & & & 0.10 & 0.507 & & \\
\hline Informational support & -0.20 & 0.346 & & & -0.33 & 0.061 & & \\
\hline $\begin{array}{l}\text { № of members } \\
\text { in network }\end{array}$ & 0.29 & 0.605 & & & -0.35 & 0.445 & & \\
\hline Sex & -0.01 & 0.997 & & & 5.12 & 0.184 & & \\
\hline Age & -0.30 & 0.309 & & & -0.55 & 0.012 & & \\
\hline Schooling & 2.49 & 0.000 & & & 3.64 & 0.000 & & \\
\hline$N^{\circ}$ of diseases & 0.37 & 0.586 & & & -0.25 & 0.725 & & \\
\hline $\begin{array}{l}\text { No of depressive } \\
\text { symptoms }\end{array}$ & -0.87 & 0.227 & & & -0.28 & 0.612 & & \\
\hline
\end{tabular}

\section{DISCUSSION}

In the present study, differences were found between caregivers and non-caregivers regarding marital status, the number of residents in the home, and monthly family income, with a greater proportion of older adults who live with a partner, have a higher family income, and reside with a greater number of individuals in the group of caregivers. These differences may be related to the family arrangements of individuals who offer care to a spouse and reside with a larger number of people, which consequently leads to a larger family income. A previous study conducted in Brazil with 343 older caregivers living in different contexts found that the majority who provided care for a spouse resided with two or three people ${ }^{(27)}$.

No significant difference was found regarding the mean ACE-R score between caregivers (62.3 points; SD: 1.8 ) and non-caregivers (62.0 points; SD: 1.9). The cognitive performance depends on the degree of dependence of the person being cared for and on their cognitive decline ${ }^{(28)}$. In the present study, care is offered to people dependent on at least one BADL or IADL, which does not necessarily characterize considerable dependence. Previous studies reported a poorer cognitive performance by caregivers of older adults with dementia, whose greater dependence makes the task of caring more difficult and therefore, with a greater impact on the health of the caregiver ${ }^{(29-31)}$. Moreover, the two groups in the present study were 
composed of older adults with similar characteristics in terms of age, schooling, number of diseases, and number of depressive symptoms.

The findings also demonstrated an association between cognition and schooling in both groups. The literature indicates that schooling plays an important role in cognition; older adults with little schooling have a greater chance of exhibiting cognitive decline and dementia as they age ${ }^{(32-34)}$. Moreover, a lower educational level in early life is a risk factor for cognitive decline that exerts a much stronger influence than ageing itself ${ }^{(35)}$. In a study conducted with 630 older Brazilians to provide normative data for the ACE-R considering different educational levels, the scores on the total ACE-R and different domains varied significantly according to educational level, sex, and age ${ }^{(36)}$. Age was a factor related to cognition only in the group of non-caregivers. Age is considered an important predictor of cognitive impairment ${ }^{(34,37)}$, as changes stemming from the ageing process can result in the progressive decline of cognitive functions ${ }^{(38)}$.

In the present study, family income was associated with cognitive performance. In a multicenter study conducted with older adults involving linear regression analysis, those with a lower income had a worse performance on the cognitive test. The authors suggest that the poorer cognitive performance among older adults with a low income may be related to less access to stimuli in this portion of the population ${ }^{(39)}$.

The present analyzes revealed significant associations between cognitive function and specific domains of social support. Among caregivers, cognitive performance (ACE-R score) was associated with receiving emotional support. Among non-caregivers, cognitive performance was higher among those who received both emotional and affectionate support. In the context of care, emotional support regards assistance for the satisfaction of emotional and confidential needs as well as encouragement. Affectionate support in this context regards explicit, even physical demonstrations of affection, such as a kissing, hugging, touching, or the simple perceived presence of another person ${ }^{(40)}$.

The affectionate support was not associated with cognitive performance in the group of caregivers. A possible explanation would be that these individuals provided care mainly for spouses and therefore, cohabitate with the care recipient, who may offer them affectionate support. Emotional support in the group of caregivers was associated with cognition, reflecting the need to have someone with whom to talk and people available to offer sincere, understanding attention.

In multiple linear regression analysis between the characteristics of the support network and performance on the ACE-R in the group of non-caregivers, each one-point increase in the emotional support score and affectionate support score was related to a 0.43-point ( $p=0.033)$ and 0.39-point $(p=0.011)$ increase in the ACE-R score, respectively. In the group of caregivers, each one-point increase in the emotional support score was related to a 0.55 -point increase in the ACE-R score.

Social support and its variations of emotional support are reported to be important protection factors against outcomes affecting physical and psychological health ${ }^{(7,41)}$. Receiving support can provide a positive view of life and stressful situations, thereby ensuring the ability to cope with adversity ${ }^{(8,42)}$. Even extreme situations, such as an excessive care burden, can be minimized by social support and coping mechanisms ${ }^{(8,43)}$.
Support networks, material/emotional support and social activities are associated with better cognitive function and a lower risk of cognitive decline $e^{(2,44-46)}$. The psychological response of the caregiver is not linear, and low levels of care-related stress may be associated with benefits in providing care ${ }^{(47)}$. Some studies have demonstrated the positive effects of support on psychological and physical wellbeing in caregivers ${ }^{(7,45,48-49)}$. In a study conducted with Chinese caregivers, perceived stress was the strongest predictor of anxiety symptoms, but social support might assist in alleviating anxiety symptoms from the stress of caregiving ${ }^{(50)}$.

Care activities are often associated with social isolation, as daily care requires exclusive attention to household tasks and activities related to the care recipient ${ }^{(49,51)}$. Therefore, counting on the support of others for encouragement implies improvements in wellbeing and a sense of social belonging on the part of caregivers, which can minimize the possible risks of chronic diseases and death ${ }^{(49,52)}$.

\section{Study limitations}

The primary limitation of this study is the cross-sectional design carried out with a specific sample of older caregivers. It was not possible to identify the temporal precedence of the factors studied, compromising the evidence of cause and effect relationships over time, and data cannot be generalized. We emphasize the importance of new investigations in this area to support health services in planning appropriate assistance.

\section{Contributions to Nursing, Health or Public Policy}

The findings of the present study serve to alert health professionals about the association between better cognitive performance and greater perception of social support. Furthermore, can support health services in planning appropriate care, aiming at strengthen the support network and have a positive impact on the cognitive, physical and psychological health of the older person, with an emphasis on older caregivers.

\section{CONCLUSION}

The present findings reveal a significant association between a better cognitive performance (ACE-R score) and greater emotional support among older caregivers. Moreover, significant associations were found between a better cognitive performance and both greater emotional and affectionate support among non-caregivers.

Considering the fundamental role of families in providing care for dependent older adults and the structure of social support networks in old age, strengthening the support networks of older caregivers and encouraging satisfactory exchanges of social support, especially with regards to emotional support, can assist in improving cognitive performance, which can have a positive impact on caregivers' health and the quality of the care offered.

\section{FUNDING}

This work was supported by the Conselho Nacional de Desenvolvimento Científico e Tecnológico (Grant number 304068/2015-6) and the Fundação de Amparo à Pesquisa do Estado de São Paulo (Grant number 2017/04129-9). 


\section{REFERENCES}

1. Plöthner M, Schmidt K, Jong L, Zeidler J, Damm K. Needs and preferences of informal caregivers regarding outpatient care for the elderly: a systematic literature review. BMC Geriatrics. 2019;19:82. doi: 10.1186/s12877-019-1068-4

2. Pavarini SCI, Brigola AG, Ottaviani AC, Luchesi BM, Souza ÉN, Rossetti ES, et al. Factors associated with cognitive performance in elderly caregivers. Arq Neuropsiquiatr. 2018;76(10):685-91. doi: 10.1590/0004-282X20180101

3. Díaz M, Estévez A, Momeñe J, Ozerinjauregi N. Social support in the relationship between perceived informal caregiver burden and general health of female caregivers. Ansiedad Estres. 2019;25(1):20-7. doi: 10.1016/j.anyes.2019.04.001

4. Santos-Orlandi AA, Brigola AG, Ottaviani AC, Luchesi BM, Souza ÉN, Moura FG, et al. Elderly caregivers of the elderly: frailty, loneliness and depressive symptoms. Rev Bras Enferm. 2019;72(Suppl2):88-96. doi: 10.1590/0034-7167-2018-0137

5. Bom J, Bakx P, Schut F, Van Doorslaer E. The impact of informal caregiving for older adults on the health of various types of caregivers: a systematic review. Gerontologist. 2019;59(5):e629-e642. doi: 10.1093/geront/gny137

6. Lino VTS, Rodrigues NCP, Camacho LAB, O'Dwyer G, Lima IS, Andrade MKN, et al. Prevalence of overburden in caregivers of dependent elderly and associated factors in a poor area of Rio de Janeiro, Brazil. Cad Saude Publica. 2016;32(6):e00060115. doi: $10.1590 / 0102-311$ X00060115

7. del-Pino-Casado R, Frías-Osuna A, Palomino-Moral PA, Ruzafa-Martínez M, Ramos-Morcillo AJ. Social support and subjective burden in caregivers of adults and older adults: a meta-analysis. Xia Y, editor. PLoS One. 2018;13(1):e0189874. doi: 10.1371/journal.pone.0189874

8. Ong HL, Vaingankar JA, Abdin E, Sambasivam R, Fauziana R, Tan ME, et al. Resilience and burden in caregivers of older adults: Moderating and mediating effects of perceived social support. BMC Psychiatry. 2018;18(1):27. doi: 10.1186/s12888-018-1616-z

9. Neri AL, Vieira LAM. Envolvimento social e suporte social percebido na velhice. Rev Bras Geriatr Gerontol. 2013;16(3):419-32. doi: 10.1590/ S1809-98232013000300002

10. Guedes MBOG, Lima KC, Caldas CP, Veras RP. Social support and comprehensive health care for the elderly. Physis. 2017;27(4):1185-204. doi: $10.1590 / \mathrm{s} 0103-73312017000400017$

11. Sant'Ana LAJ, D'Elboux MJ. Suporte social e expectativa de cuidado de idosos: associação com variáveis socioeconômicas, saúde e funcionalidade. Saúde Debate. 2019;43(121):503-19. doi: 10.1590/0103-1104201912117

12. Baron M, Riva M, Fletcher C. The social determinants of healthy ageing in the Canadian Arctic. Int J Circumpolar Health. 2019;78(1):1630234. doi: $10.1080 / 22423982.2019 .1630234$

13. Ali T, Nilsson CJ, Weuve J, Rajan KB, Mendes-de-Leon CF. Effects of social network diversity on mortality, cognition and physical function in the elderly: a longitudinal analysis of the Chicago Health and Aging Project (CHAP). J Epidemiol Community Health. 2018;72(11):990-6. doi: 10.1136/jech-2017-210236

14. Zhong Y, Wang J, Nicholas S. Social support and depressive symptoms among family caregivers of older people with disabilities in four provinces of urban China: the mediating role of caregiver burden. BMC Geriatr. 2020;20(1):1-10. doi: 10.1186/s12877-019-1403-9

15. Bui BKH. The relationship between social network characteristics and depressive symptoms among older adults in the United States: differentiating between network structure and network function. Psychogeriatrics. 2020;psyg.12530. doi: 10.1111/psyg.12530

16. James BD, Wilson RS, Barnes LL, Bennett DA. Late-Life social activity and cognitive decline in old age. J Int Neuropsychol Soc. 2011;17(6):998. doi: 10.1017 / S1355617711000531

17. Wang X. Subjective well-being associated with size of social network and social support of elderly. J Health Psychol. 2016;21(6):1037-42. doi: $10.1177 / 1359105314544136$

18. Anjos KF, Oliveira Boery RNS, Pereira R, Pedreira LC, Vilela ABA, Santos VC, et al. Association between social support and quality of life of relative caregivers of elderly dependents. Cien Saude Coletiva. 2015;20(5):1321-30. doi: 10.1590/1413-81232015205.14192014

19. Kotwal AA, Kim J, Waite L, Dale W. Social Function and Cognitive Status: Results from a US Nationally Representative Survey of Older Adults. J Gen Intern Med. 2016;31(8):854-62. doi: 10.1007/s11606-016-3696-0

20. Kuiper JS, Zuidersma M, Oude Voshaar RC, Zuidema SU, van den Heuvel ER, Stolk RP, et al. Social relationships and risk of dementia: a systematic review and meta-analysis of longitudinal cohort studies. Ageing Res Rev. 2015;22:39-57. doi: 10.1016/j.arr.2015.04.006

21. Hulley SB, Cummings SR, Browner WS, Grady DG, Newman TB. Designing Clinical Research. 4th ed. Lippincott Williams \& Wilkins: Philadelphia; 2013. 367 p.

22. Lino VTS, Pereira SRM, Camacho LAB, Ribeiro Filho ST, Buskman S. Cross-cultural adaptation of the Independence in Activities of Daily Living Index (Katz Index). Cad Saúde Pública. 2008;24(1):103-12. doi: 10.1590/S0102-311X2008000100010

23. Santos RL, Virtuoso Jr JS. Reliability of the Brazilian version of the Scale of Instrumental. Rev Bras Promoç Saúde. 2008;21(4):290-6. doi: $10.1590 /$ S0102-311X2008000100010

24. Griep RH, Chor D, Faerstein E, Werneck GL, Lopes CS. Construct validity of the Medical Outcomes Study's social support scale adapted to Portuguese in the Pró-Saúde Study. Cad Saúde Pública. 2005;21(3):703-14. doi: 10.1590/S0102-311X2005000300004 
25. Carvalho VA, Caramelli P. Brazilian adaptation of the Addenbrooke's Cognitive Examination-Revised (ACE-R). Dement Neuropsychol. 2007;2:212-6. doi: 10.1590/s1980-57642008dn10200015

26. Almeida OP, Almeida SA. Reliability of the Brazilian version of the geriatric depression scale (GDS) short form. Arq Neuropsiquiatr. 1999;57(2 B):421-6. doi: 10.1590/S0004-282X1999000300013

27. Pavarini SCl, Neri AL, Brigola AG, Ottaviani AC, Souza ÉN, Rossetti ES, et al. Elderly caregivers living in urban, rural and high social vulnerability contexts. Rev Esc Enferm USP. 2017;51(0):e03254. doi: 10.1590/s1980-220x2016040103254

28. Zwar L, König HH, Hajek A. The impact of different types of informal caregiving on cognitive functioning of older caregivers: evidence from a longitudinal, population-based study in Germany. Soc Sci Med. 2018;214:12-9. doi: 10.1016/j.socscimed.2018.07.048

29. Pertl MM, Lawlor BA, Robertson IH, Walsh C, Brennan S. Risk of cognitive and functional impairment in spouses of people with dementia: evidence from the health and retirement study. J Geriatr Psychiatry Neurol. 2015;28(4):260-71. doi: 10.1177/0891988715588834

30. Vitaliano PP, Murphy M, Young HM, Echeverria D, Borson S. Does caring for a spouse with dementia promote cognitive decline? a hypothesis and proposed mechanisms. J Am Geriatr Soc. 2011;59(5):900-8. doi: 10.1111/j.1532-5415.2011.03368.x

31. Dassel KB, Carr DC, Vitaliano P, Pruchno R. Does caring for a spouse with dementia accelerate cognitive decline? findings from the health and retirement study. Gerontol. 2017;57(2):319-28. doi: 10.1093/geront/gnv148

32. Frankish H, Horton R. Prevention and management of dementia: a priority for public health. Lancet. 2017;(390)2614-5. doi: 10.1016/ S0140-6736(17)31756-7

33. Nascimento RASA, Batista RTS, Rocha SV, Vasconcelos LRC, Nascimento RASA, Batista RTS, et al. Prevalence and factors associated with the decline in the elderly with cognitive low economic condition: MONIDI study. J Bras Psiquiatr. 2015;64(3):187-92. doi: 10.1590/0047-2085000000077

34. Brigola AG, Ottaviani AC, Souza ÉN, Rossetti ES, Terassi M, Oliveira NA, et al. Descriptive data in different paper-based cognitive assessments in elderly from the community Stratification by age and education. Dement Neuropsychol. 2018;12(2):157-64. doi: 10.1590/1980-57642018dn12-020008

35. Bento-Torres NVO, Bento-Torres J, Tomás AM, Costa VO, Corrêa PGR, Costa CNM, et al. Influence of schooling and age on cognitive performance in healthy older adults. Brazilian J Med Biol Res. 2017;50(4):e5892. doi: 10.1590/1414-431x20165892

36. César KG, Yassuda MS, Porto FHG, Brucki SMD, Nitrini R. Addenbrooke's cognitive examination-revised: normative and accuracy data for seniors with heterogeneous educational level in Brazil. Int Psychogeriatrics. 2017;29(8):1345-53. doi: 10.1017/S1041610217000734

37. Melo BRS, Diniz MAA, Casemiro FG, Figueiredo LC, Santos-Orlandi AA, Haas VJ, et al. Cognitive and functional assessment about elderly people users of health public service. Esc Anna Nery. 2017;21(4). doi: 10.1590/2177-9465-ean-2016-0388

38. Jockwitz C, Caspers S, Lux S, Eickhoff SB, Jütten K, Lenzen S, et al. Influence of age and cognitive performance on resting-state brain networks of older adults in a population-based cohort. Cortex. 2017;89:28-44. doi: 10.1016/j.cortex.2017.01.008

39. Santos AA, Mansano-Schlosser TCS, Ceolim MF, Pavarini SCI. Sleep, fragility and cognition: a multicenter study with Brazilian elderly. Rev Bras Enferm. 2013;66(3):351-7. doi: 10.1590/S0034-71672013000300008

40. Andrade CR, Chor D, Faerstein E, Griep RH, Lopes CS, Fonseca MDJM. Apoio social e auto-exame das mamas no Estudo Pró-Saúde. Cad Saude Publica. 2005;21(2):379-86. doi: 10.1590/S0102-311X2005000200004

41. Melchiorre MG, Chiatti C, Lamura G, Torres-Gonzales F, Stankunas M, Lindert J, et al. Social support, socio-economic status, health and abuse among older people in seven European Countries. PLoS One. 2013;8(1):e54856. doi: 10.1371/journal.pone.0054856

42. Manzini CSS, Vale FAC. Resilience of family caregivers of elderly with Alzheimer. Rev Eletrôn Enferm. 2016;18:e1190. doi: 10.1590/1809-98232016019.150117

43. Serra L, Contador I, Fernández-Calvo B, Ruisoto P, Jenaro C, Flores N, et al. Resilience and social support as protective factors against abuse of patients with dementia: a study on family caregivers. Int J Geriatr Psychiatry. 2018;33(8):1132-8. doi: 10.1002/gps.4905

44. Ottaviani AC, Bregola AG, Terassi M, Luchesi BM, Souza ÉN, de Oliveira NA, et al. Comparison of cognitive performance and aspects of the care context in elderly caregivers in Brazil a follow-up study. Dement Neuropsychol. 2020;14(2):159-64. doi: 10.1590/1980-57642020dn14-020009

45. Dam AEH, Vugt ME, Klinkenberg IPM, Verhey FRJ, Van Boxtel MPJ. A systematic review of social support interventions for caregivers of people with dementia: are they doing what they promise?, Maturitas. 2016;85:117-30. doi: 10.1016/j.maturitas.2015.12.008

46. Penninkilampi R, Casey AN, Singh MF, Brodaty H. The Association between social engagement, loneliness, and risk of dementia: a systematic review and meta-analysis. J Alzheimer's Dis. 2018;1;66(4):1619-33. doi: 10.3233/JAD-180439

47. Roth DL, Fredman L, Haley WE. Informal caregiving and its impact on health: a reappraisal from population-based studies. Gerontologist. 2015;55(2):309-19. doi: 10.1093/geront/gnu177

48. Shiba K, Kondo N, Kondo K. Informal and formal social support and caregiver burden: the AGES caregiver survey. J Epidemiol. 2016;26(12):622-8. doi: 10.2188/jea.JE20150263

49. Vasileiou K, Barnett J, Barreto M, Vines J, Atkinson M, Lawson S, et al. Experiences of loneliness associated with being an informal caregiver: a qualitative investigation. Front Psychol. 2017;8:585. doi: 10.3389/fpsyg.2017.00585

50. Shi J, Huang A, Jia Y, Yang X. Perceived stress and social support influence anxiety symptoms of Chinese family caregivers of communitydwelling older adults: a cross-sectional study. Psychogeriatrics. 2020;10.1111/psyg.12510. doi: 10.1111/psyg.12510 
51. Carmeli E. The invisibles: unpaid caregivers of the elderly. Front Public Health. 2014;2:91. doi: 10.3389/fpubh.2014.00091

52. Liu B, Floud S. Unravelling the associations between social isolation, loneliness, and mortality. Lancet Public Health. 2017;2:e248-9. doi: 10.1016/S2468-2667(17)30090-7 